\title{
On testicular cooling in phocid seals*
}

\author{
ARNOLDUS SCHYTTE BLIX, FRANCIS H. FAY AND KEITH RONALD
}

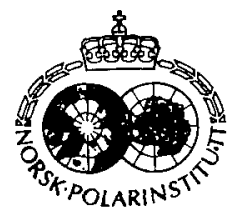

Blix, A. S., Fay, F. H. \& Ronald, K. 1983: On testicular cooling in phocid seals. Polar Research I n.s., 231-233.

Testicular and body core (intra-thoracic) temperatures were recorded in mature male harp seals (Pagophilus groenlandicus) just prior to the mating season. In phocid seals the testicles are outside the abdomen but protected under $7-8 \mathrm{~cm}$ of insulating skin and blubber. The temperature of the testicles was found to be $1-4^{\circ} \mathrm{C}$ lower than body core temperature. Inspection of the veins of the pelvic and hind-flipper region of a male ribbon seal (Histriophoca faciata) revealed that the testicles of phocid seals are enveloped in venous plexuses communicating with the veins of the hind flippers. It is suggested that cooling of the paraabdominal testicles of phocid seals is attained by passage of cold blood from the hind flippers through the extra-testicular plexuses.

Arnoldus Schytte Blix, Department of Arctic Biology and Institute of Medical Biology, University of Troms $\emptyset$, Troms $\emptyset$, Norway; Francis H. Fay, Institute of Marine Science, University of Alaska, Fairbanks, Alaska, U.S.A.; Keith Ronald, College of Biological Science, University of Guelph, Ontario, Canada.

\section{Introduction}

The seals, sea lions, and walruses are placed under two super-families, the Otarioidea and the Phocoidea. The Otarioidea have hind flippers which can turn forward and assist in a sort of four-footed locomotion, while the Phocoidea move in a snake-like and/or humping manner close to the ground. For this, or other reasons, the Phocoidea do not have a scrotum, while the Otarioidea do. In most mammals the testicles lose their sexual potency unless they are kept at a temperature lower than that of body core, and to the best of our knowledge the purpose of the scrotum is to keep the testicles cool. Scientists have tended to neglect the importance of phocid seal testicles but the temperature of the sexual glands of fur seals (Callorhinus ursinus) is known to be at least $6^{\circ} \mathrm{C}$ lower than body core temperature (Bartholomew \& Wilke 1956).

The purpose of the present study was to determine the temperature of the testicles of the harp seal (Pagophilus groenlandicus) which, unlike the fur seal, carries its sexual glands against the abdomen under $7-8 \mathrm{~cm}$ of insulating blubber. We found that the testicles of the harp seal are cool, and suggest why this is so.

\footnotetext{
- Presented in part at the 29 th Alaska Science Conference, 15-17 August, 1978.
}

\section{Material and methods}

Four mature male harp seals (Pagophilus groenlandicus) were shot while lying on the ice of the Gulf of St. Lawrence, Canada, on 4 March (just prior to the mating season). The weather was sunny, with no wind and an ambient temperature of $-7^{\circ} \mathrm{C}$. Subsequent to an immediate death, body core (intra-thoracic) temperature and the temperature in the centre of both testicles were meas-

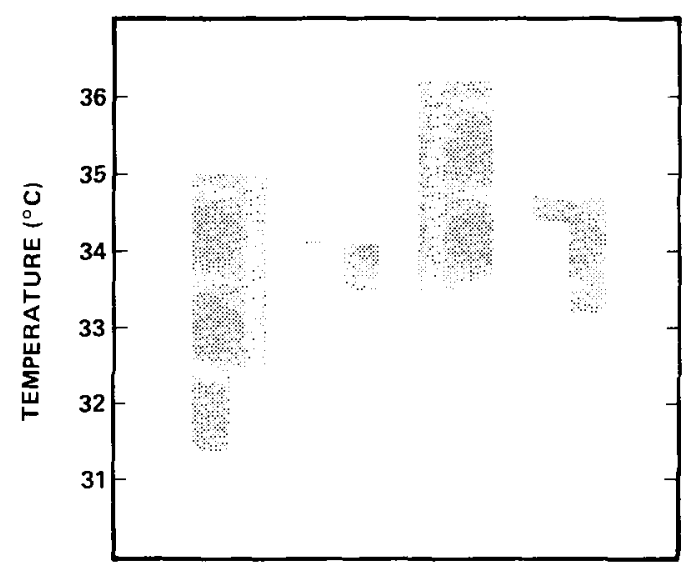

Fig. 1. Body core (intra-thoracic) temperature (upper margin of columns) and the temperature of each of the two testicles (lower margins of columns) of four different mature male harp seals (Pagophilus groenlandicus) recorded immediately after death. When killed (just prior to the mating season) the animals were lying on the sea ice in calm, sunny weather with an ambient temperature of $-7^{\circ} \mathrm{C}$. 
ured by the use of calibrated copper-constantan thermocouples mounted inside $10 \mathrm{~cm}$ long hypodermic needles and connected to a Fluke ${ }^{\mathbb{B}}$ thermometer (accuracy $\pm 0.1^{\circ} \mathrm{C}$ ) operating on $\mathrm{Li}$ batteries.

One male ribbon seal (Histriophoca faciata) carcass was injected with red vinyl resin (Turtox, Chicago. Ill. . USA) into the abdominal aorta and yellow into the plantar digital vein of each hind flipper. The carcass was then refrigerated at $4^{\circ} \mathrm{C}$ for four days before being put into concentrated hydrochloric acid for tissue digestion. Tissue a scrotum, and carry their testicles against the abdomen under a thick layer of blubber, their testicles are cooler than the body core (Fig. 1). The largest difference between testicular and body core temperature was $3.6^{\circ} \mathrm{C}$, the average testicular temperature being $33.3 \pm 0.5$ (SD, $\mathrm{n}=8$ ). The temperatures of the two glands in each animal, however, often differed, in one case by as much as $1.2^{\circ} \mathrm{C}$. At the moment we can only suggest that this difference is due to lax regulation of testicular temperature in this species. This view is further supported by the fact that average tes-

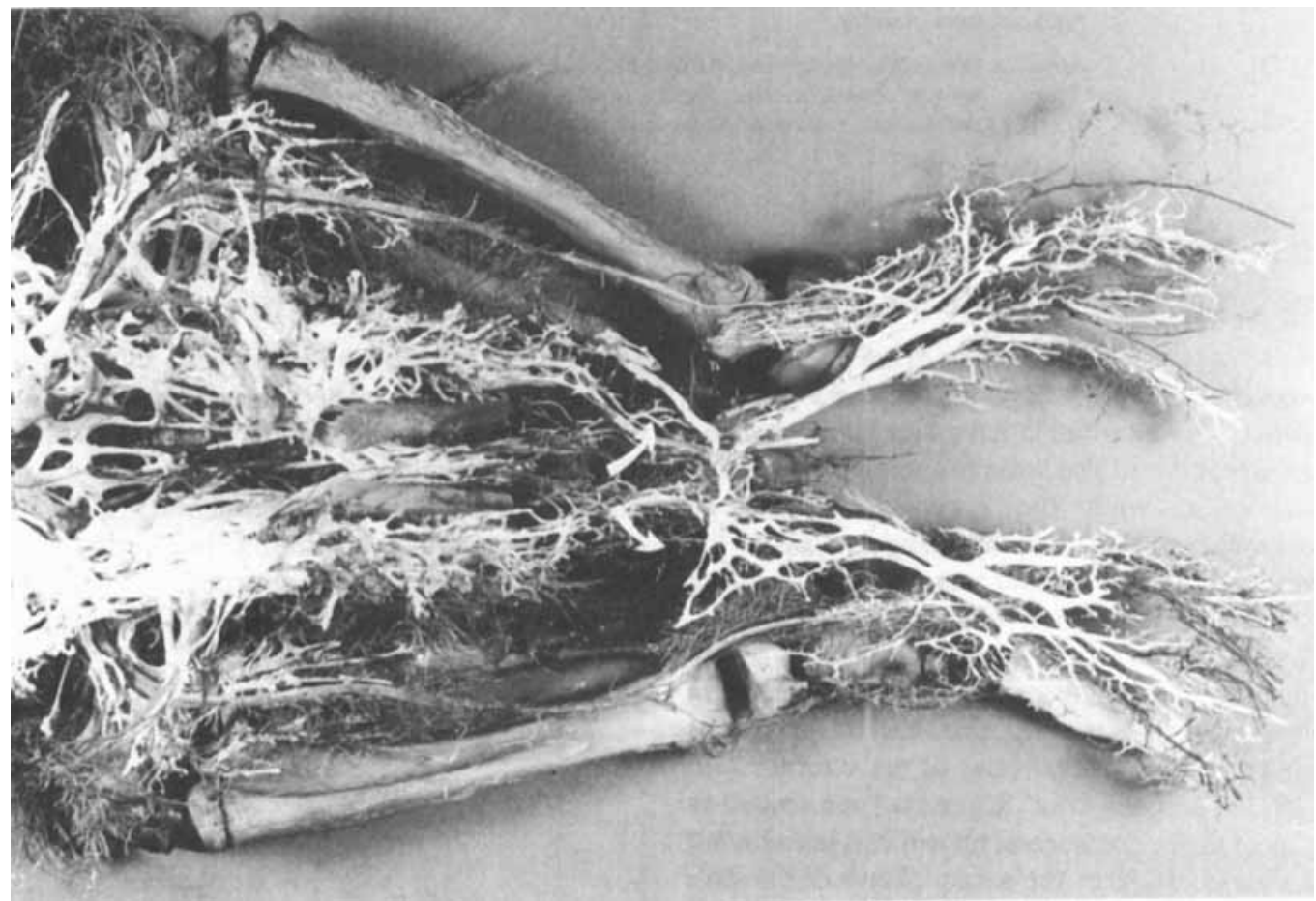

Fig. 2. Photograph of plastic casts of the venous (white) and arterial (grey) vascular beds of the pelvic and hind-flipper regions of a male ribbon seal (Histriophoca faciata) showing a conspicuous venous connection from the hind flippers to extra-testicular venous plexuses. Also shown are the hind leg and flipper bones of the same regions. The remains of the animal lie ventral side up, with the hind flippers extending to the right. The location of the testicles is indicated by arrows.

digestion was terminated only when the plastic cast and the skeleton of the animal were left. After rinsing in water the cast was photographed.

\section{Results and discussion}

In spite of the fact that phocid seals do not have ticular temperature differed by as much as $1.9^{\circ} \mathrm{C}$ between individuals.

Unlike most mature mammals we also found that body core temperature varied by as much as $2.1^{\circ} \mathrm{C}$ between different animals. Moreover, average body core temperature was as low as 35.0 $\pm 0.4^{\circ} \mathrm{C}(\mathrm{SD}, \mathrm{n}=4)$, with a liberal range from $34.1^{\circ} \mathrm{C}$ to $36.2^{\circ} \mathrm{C}$ (Fig. 1). This surprisingly low 
average value and the variability among individuals compare with data recently obtained by the use of radio telemetry in free swimming seals of the same species (Gallivan \& Ronald 1979).

Figure 2 shows a cast obtained after injection of coloured vinyl resins into the abdominal aorta and plantar digital veins of a male ribbon seal, which is closely related to the harp seal. The cast shows a conspicuous venous connection between the hind flippers and extra-testicular plexuses, the latter being only partly filled with plastic (Fig. 2).

On the basis of these results we venture to suggest that the observed cooling of the paraabdominal testicles of phocid seals is caused by the passage of cold blood from the hind-flipper veins to extra-testicular venous plexuses. If this is indeed the case, testicle temperature would be even less if the animals, instead of basking in the sun, were swimming in ice water, as such seals are supposed to do during the mating season.

\section{References}

Bartholomew, G. A. \& Wilke, F, 1956: Body temperature in the northern fur seal (Callorhinus ursinus). J. Mamm. 37, 327-337.

Gallivan, G. J. \& Ronald. K. 1979: Temperature regulation in freely diving harp seals (Phoca groenlandica), Can. J. Zool. 57. 2256-2263. 
